Ege Tıp Dergisi / Ege Journal of Medicine 2016;55(2):92-94

\title{
Akut apandisiti taklit eden primer omentum torsiyonu
}

\section{Primer omental torsion mimicking acute appendicitis}

\author{
Sevgi Büyükbeşe Sarsu ${ }^{1} \quad$ Kamil Şahin $^{2} \quad$ Wassim Almahli $^{3}$ \\ ${ }^{1}$ Gaziantep Çocuk Hastanesi, Çocuk Cerrahisi Kliniği, Gaziantep, Türkiye \\ ${ }^{2}$ Haseki Eğitim ve Araştırma Hastanesi, Çocuk Sağlığı ve Hastalıkları Kliniği, İstanbul, Türkiye \\ ${ }^{3}$ Gaziantep Üniversitesi Tıp Fakültesi, Genel Cerrahi Anabilim Dalı, Gaziantep, Türkiye
}

\section{Öz}

Primer omentum torsiyonu (POT), genellikle obez erkeklerde rastlanılan akut batının az görülen bir nedenidir. Çocukluk döneminde çok nadir karşılaşılan bu durum, akut apandisite çok benzediği için preoperatif tanı koymak zordur. Bu yazıda, iki günden bu yana devam eden karın ağrısı, ateş ve kusma nedeniyle hastaneye başvuran 11 yaşında bir erkek çocuğu sunulmaktadır. Fizik muayenede, sağ alt kadranda hassasiyet mevcuttu. Beyaz küredeki yükselme dışında, ayakta direk batın grafisi ve karın ultrasonografisinde özellik yoktu. Apandisit ön tanısı ile sağ alt kadrana yapılan transvers kesi ile yapılan laparotomide, apendiksin normal olduğu ancak sağ iliak fossada omentumun dönmüş olduğu tespit edildi. Batın içi serbest sıvı dışında başka bir patolojik patolojinin olmadığı tespit edildikten sonra hastaya apendektomi ve omentektomi yapıldı. Postoperatif komplikasyon yaşanmadı. Her ne kadar nadir rastlanan bir durum olsa da, akut apandisit için laparotomi yapılan hastalarda, apendiks normal ise, omentum torsiyonu olabileceği göz ardı edilmemelidir.

Anahtar Sözcükler: Primer omentum torsiyonu, akut apandisit, çocuklar.

\begin{abstract}
Primary omental torsion (POT) is a rare cause of acute abdomen usually seen in the obese men. It is very rarely seen in the childhood, and as it mimicks acute appendicitis, preoperative diagnosis is difficult. In this report, we present a eleven-year-old boy admitted to the hospital with abdominal pain, fever and vomitting lasting for two days. Physical examination revealed tenderness in the right lower quadrant. White blood cell account was raised, whereas direct abdominal graphy and ultrasonography were normal. The patient was prediagnosed as acute appendicitis, and a transverse laparotomy incision was made. Appendix was normal but omental torsion was seen in the right iliac fossa. There was not any pathologic lesion other than free fluid in the abdominal cavity. Appendectomy and omentectomy was performed. No postoperative complication was noted. Although torsion of the omentum is a rare cause of acute abdomen; it must not be abscent of the surgeon mind when the patients undergoing laparotomy for acute appendicitis, $t$ should not be kept in mind.
\end{abstract}

Keywords: Primary omental torsion; acute appendicitis; children.

\section{Giriş}

Akut batının az rastlanan bir nedeni olan primer omentum torsiyonu (POT), çoğu zaman yaşamının dördüncü, beşinci dekadındaki obez erkek hastalarda görülür (1). Çocuklarda ise son derece nadirdir (2). POT, omentum majusun kendi uzun ekseni boyunca dönmesi sonucu gelişen, hemorajik iskemik infarkt ve yağ nekrozu ile karakterize bir hastalıktır. Omentum infarktı, tam olarak inflamatuar sürecin retraksiyon, fibrozis, komplet rezolüsyonu ya da kendiliğinden amputasyonuna denir.

Yazışma Adresi: Sevgi Büyükbeşe Sarsu

Gaziantep Çocuk Hastanesi, Çocuk Cerrahisi Anabilim Dalı, Gaziantep, Türkiye

Makalenin Geliş Tarihi: 02.12.2014

Kabul Tarihi: 02.03.2015
Hastalığın geç dönem komplikasyonları ise abse, adezyon ve sepsisdir. Klinik özellikleri ve laboratuar bulguları bakımından akut apandisite çok benzediği için çocukluk çağında, preoperatif tanı koymak zordur $(3,4)$. Bu yüzden tanı, çoğu zaman laparatomi esnasında konulur. Obezite, POT'a yatkınlığı artıran en önemli risk faktörü olarak kabul edilebilir (4). Her ne kadar bazı yazarlar tarafından konservatif yaklaşımın başarılı olacağı ileri sürülmüş olsa da, POT'da iskemik omentumun eksizyonu ideal tedavidir $(5,6)$. Bu çalışmamızda akut apandisit nedeniyle laparotomi yapılan bir çocukta primer omentum torsiyonu olgusunu literatür ile birlikte değerlendirdik.

\section{Olgu Sunumu}

Gaziantep Çocuk Hastanesi Çocuk Cerrahisi Kliniği'ne devamlı ve yayılım göstermeyen sağ alt kadran ağrısı 
nedeniyle kabul edilen 11 yaşındaki erkek çocuğun semptomlarına, yatışının 24. saatinde ateş, bulantı ve kusma şikayetleri de eklendi Fizik muayenede sağ alt kadranda hassasiyeti mevcut olup, diğer sistem muayeneleri doğaldı. Ağırık 59 kg (>97p) boy $148 \mathrm{~cm}(75 p)$ ölçüldü. Ayakta direk karın grafisi ve ultrasonografide (USG) patolojik bulguya rastlanmadı. Beyaz küre $14 \times 10^{3}$, CRP 0.68 idi. Apandisit ön tanısı ile sağ alt kadrana transvers kesi ile yapılan laparotomide, intraperitoneal seroz içerikli sıvı aspire edildi. Eksplorasyonda, nekrotik sert kitle görünümündeki omentumun 720 derece torsiyone olduğu, distalinden herhangi bir yere yapışık olmadığı görüldü (Şekil-1a,b). Apendiksin normal olduğu, ek başka patolojik lezyonun olmadığı tespit edildikten sonra apendektomi ile nekroze olan omentumun vasküler pedikülüne klemp konularak parsiyel omentektomi yapıldı. Peritoneal kültürde üreme tespit edilmedi. Histopatolojik değerlendirmede, omental kitlenin vasküler konjesyonu, hemorajik iskemik nekrozu ve non-spesifik inflamasyonu ile normal apendiks vermiformis tespit edildi. Postoperatif komplikasyon yaşanmayan hasta, yatışının dördüncü gününde taburcu edildi.

Hastanın ebeveynlerinden tıbbi verilerinin yayınlanabileceğine ilişkin yazılı onam belgesi alındı.

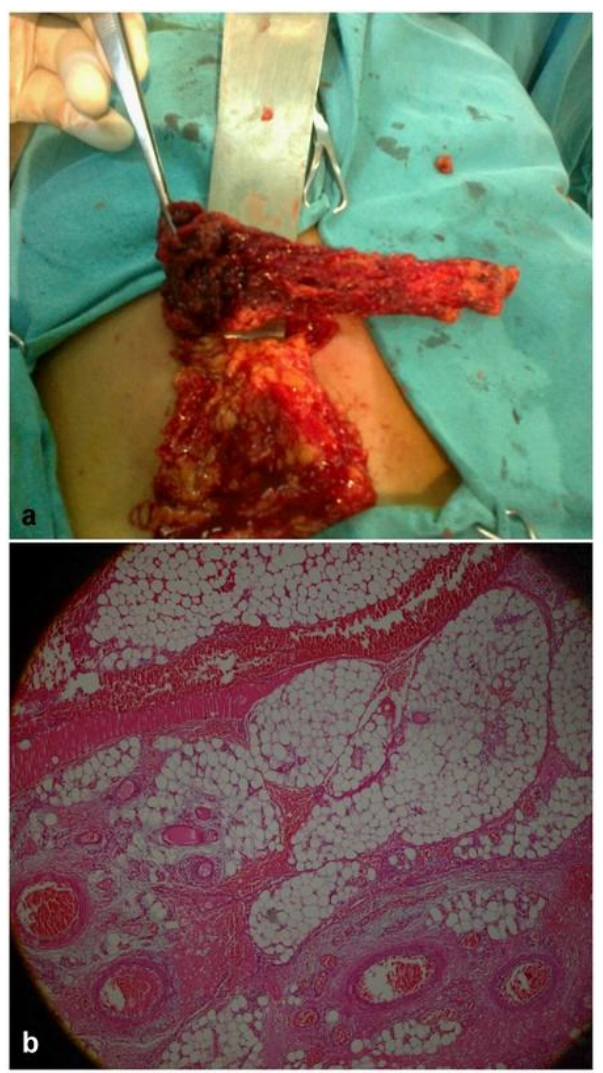

Şekil-1. a.Torsiyone omentumun nekrotik görünümü. b. Omentumda hemoraji, konjesyon ve non-spesifik inflamasyon izlenmekte (H\&E x40).

\section{Tartışma}

Omentum torsiyonu, omentum majusun perfüzyonunun bozulması sonucu gelişen bir durum olup ilk kez 1889'da tanımlanmıştır. Primer ya da sekonder olabilir. Omentumun, batın içinde bir patolojik durum olmadan kendi ekseni etrafında dönmesine ise POT denir ve vakaların üçte birini oluşturur. İnsidansı yaklaşık \%0.18 olarak kabul edilir. Olguların sadece \%15'i pediatrik yaş grubundadır. Etiyolojisi tam olarak netlik kazanmamış olmasına rağmen; omentum pedikülünün anatomik varyasyonu ve bifid ya da aksesuar omentum gibi malformasyonları, özellikle de obez hastalardaki omentumun yağ dağılımındaki lokal değişiklikler, omentumun vasküler anomalileri, travma, aşırı yemeye bağlı peristaltizmindeki artış, fazla efor sarfetme, ani pozisyon değişikliğinden kaynaklanan karın içi basınç artışı, patogenezde yer aldığı düşünülen faktörler arasındadır. Obezite, hastaların yaklaşık \%70'inde bu hastalığa yatkınlık oluşturan nedendir (4). Sekonder torsiyon, primer olana göre daha yaygındır. Bu durum altta yatan kist, adezyon, herni kesesi gibi karın içi patolojinin bir sonucu olarak meydana gelir (7). POT'u olan bir hasta, genellikle aniden başlayan sağ alt kadranda ağrı ve hassasiyet ile başvurduğu için akut apandisiti taklit ederler. Ağrı lokalizasyonunun, torsiyone olan omentumun boyutuna bağlı olduğuna ve fizik muayenedeki hassasiyetin ise omentumun tutulan segmentinin lokalize olduğu saha ile uyumlu olduğuna inanıır. Bizim olgumuzda da sağ alt kadran ağrısı tabloya eşlik etmekteydi ve literatürle uyumlu olarak obezdi. Orta derecede lökositozu mevcuttu. Klinik tablo akut apandisite çok benzediği için preoperatif tanı koymak çok zordur (8). Ayırıcı tanıda yer alan diğer hastalıklar kolesistit, over kist torsiyonu ve perfore peptik ülserdir. USG ve BT tanı koymada bazen başarılı olup, konservatif tedaviye olanak sağlayabilir (9).

USG'de özellikle de hassasiyet olan bölgede, karın ön duvarının hemen altında, komprese edilemeyen, oval şekilli, hiperekoik solid kitle ve bunu çevreleyen hipoekoik bir halka saptanabilir. Yine USG'de apendiks normal saptanırken minimal asit bulunabilir. Bizim olgumuzda ise USG'de minimal asit dışında patolojiye rastlanmamıştı. BT'de asendan ve transvers kolon seviyesinde hiperintens geniş ovoid yağ tabakası ve çizgisel hiperintens görünüm saptanabilir. Kliniğimizde olguya BT çekilmedi. Apendiks normal iken, batın içi serbest Sıvı olması, primer omentum torsiyonu olasılığını düşündürmelidir. Omentum torsiyonunun esas olarak tedavisi tutulum gösteren omentum segmentinin rezeksiyonudur. РОT komplikasyonları; omental nekroz, peritonitis, barsak tıkanıklığı, adezyon ve sepsistir (10). POT tedavisinde görüş birliği henüz sağlanamamıştır. Bazı yazarlar, gelişebilecek komplikasyonlar nedeniyle cerrahi tedavi yapılması gerektiğini düşünürken, bazıları 
da, geç komplikasyonların aslında zannedildiği kadar fazla olmadığını ve konservatif tedavinin başarılı olacağını savunmaktadır. Ancak, cerrahi rezeksiyonda ağrının giderilmesi daha kolaydır ve iyileşme daha hızlıdır. Hastanedeki yatış süresi daha kısa olup, sepsis gelişme olasılığı da daha düşüktür. Medikal tedavide ise sepsis, abse ve karın içi adeziv bant gelişme riski cerrahi tedaviden daha yüksektir. Son yıllarda laparoskopik yaklaşımın POT'un hem tanı hem de tedavisinde etkili olduğu kabul edilmektedir. Omentum torsiyonu, çocuk yaş grubunda akut batının her ne kadar nadir rastlanan bir nedeni olsa da, akut apandisit için laparotomi yapılan hasta da apendiks normal ise, omentum torsiyonu olabileceği göz ardı edilmemelidir.

\section{Kaynaklar}

1. Ghosh Y, Arora R. Omental torsion. J Clin Diagn Res 2014;8(6):1-2.

2. Wertheimer J, Galloy MA, Régent D, Champigneulle J, Lemellee L. Radiological, clinical and histological correlations in a right segmental omental infarction due to primary torsion in a child. Indian J Surg 2013;75(4):255-7.

3. Khalid K, Somuah TS, Aziz E, Mohamed R, Youssef B. Primary omental torsion in children: Case report. Pan Afr Med J 2013;14(1):57.

4. Tsironis A, Zikos N, Bali C, Pappas-Gogos G, Koulas S, Katsamakis N. Acute abdomen due to primary omental torsion: Case report. J Emerg Med 2013;44(1):45-8.

5. Borgaonkar V, DeshpandeS, Rathod M, Khan I .Primary omental torsion is a diagnostic challenge in acute abdomen - a case report and literature review. Indian J Surg 2013;75(4):255-7.

6. Occhionorelli S, Zese M, Cappellari L, Stano R, Vasquez G. Acute abdomen due to primary omental torsion and infarction Case Rep Surg 2014. doi.org/10.1155/2014/208382.

7. Scabini S, Rimini E, Massobrio A, et al. Primary omental torsion: A case report. World J Gastrointest Surg 2011;3(10):153-5.

8. Andreuccetti J, Ceribelli C, Manto O, Chiaretti M, Negro P, Tuscano D. Primary omental torsion (POT): A review of literature and case report. World J Emerg Surg 2011;26(6):6.

9. Poujade, Olivier MD, Ghiles, Eva MD, Senasli, Ali MD. Primary torsion of the greater omentum: Case report-review of literature: Diagnosis cannot always be performed before surgery. Surg Laparosc Endosc Percutan Techn 2007;17(1):54-5.

10. Breunung N, Strauss PA. Diagnostic challenge: Primary omental torsion and literature review - a case report. World J Emerg Surg 2009;18(4):40. 